ACTA THERIOLOGICA

Vol. 32, 5: 51-81, 1987

\title{
Changes in the Size of the Domestic and Wild Pig in the Territory of Poland from the Neolithic to the Middle Ages
}

\author{
Alicja LASOTA-MOSKALEWSKA, Henryk KOBRYŃ \\ \& Krzysztof SWIEŻYŃSKI
}

\begin{abstract}
Lasota-Moskalewska A., Kobryń H. \& Swieżyński K., 1987: Changes in the size of the domestic and wild pig in the territory of Poland from the Neolithic to the Middle Ages. Acta theriol., 32, 5: 51-81 [With 6 Tables \& 5 Figs.].

Changes over time in six bone dimensions and height in the withers in domestic and wild pigs have been examined on the basis of materials from 120 archaeological sites in Poland. It has been established that. over a period of about 5000 years, the dimensions of the skeleton of the domestic pig have fallen more than those of the skeleton of the wild pig. The probable formative factors of the phenotype of the domesticated pig are discussed (restriction of locomotion, impoverishment of diet), as well as genetic factors (selection favouring flesh mass rather than skeletal mass). Individual morphological characteristics diminished to varying degrees, leading to changes in the proportions of the skeleton. This indicates that particular elements of the skeleton reacted differently to the same set of factors. No clear geographical variation has been noted in the characteristics examined in domesticated and wild pigs in the territory of Poland. However, a geographical differentiation has been observed between domestic pigs from Polish territory and those from other areas in the withers height. From the Neolithic through to the Middle Ages, there was a steady tendency towards the occurrence of smaller domestic pigs in Western Europe than in Eastern Europe. Pigs in Central Europe were larger than those in Southern and Northern Europe. For variously denominated dimensions of varying orders of magnitude, a common abstract scale has been constructed. The range of variability characteristic of domestic and wild pigs, and of transitional forms, which are marked on this scale facilitate the segregation of the bones of these forms in archaeozoological practice.

[Ateliers for Conservation of Cultural Properties, Senatorska 14, 00-950 Warsaw, Poland (AL-M) and Department of Animal Anatomy, Warsaw Agricultural University, Nowoursynowska 166, 02-766 Warsaw, Poland, (HK, KS)].
\end{abstract}

\section{INTRODUCTION}

There are various theories on the origins of the domestic pig. This results in part from the multiplicity of morphologically differentiated wild forms which could have been subject to domestication. Within the species Sus scrofa (Linnaeus, 1758) there are more than 20 forms clas- 
sified as sub-species, the occurrence of which has been noted in Asia, Africa and Europe (Bogolubski, 1968). More recent literature (Corbet, 1978) does not differentiate sub-species within the species Sus scrofa, but only identifies a dozen or more races, and stresses that the classification criteria are often not lighly precise. Corbet considers that this two geographically cistant forms of wild pig from the territories of Europe and Asia. However, Bogolubski (loc. cit.) and Zeuner (1963), who have studied the history of domestication, claim that the major role in the formation of the European race of domestic pigs was played by two geographically distant forms of wild pig form the territories of Eastern Asia and Europe. These authors admit the possibility that local forms of wild pigs also played a role in this domestication process, and they cite many studies on this problem. Thus the domestication of the wild pig took place both in Asia and in Europe, although in Asia it began to occur somewhat earlier: this is suggested by the dating of remains of domesticated pigs from North Eastern Iraq at about 500 years earlier than those from the territory of Greece (Bökönyi, 1983).

It is generally accepted that the domestication of animals began in the Neolithic and was linked with the "agricultural revolution" that took place at that time, and which exercised such an important influence upon the further history of man. But there are many indications that the process of domestication may have begun earlier. Bökönyi (loc. cit.) considers that dogs and pigs - animals which ate the leftovers from human food - were particularly suitable for early domestication. In support of this theory in the case of pigs, Bökönyi adduces the descriptions of porcine remains in excavated materials from Epipalaeolithic sites in Roumania and from Palaeolithic caves in the Crimean peninsula. We are inclined to support this scholar's view that the matter of whether these remains were those of domesticated forms requires further confirmation.

The keeping of domesticated pigs began on a wider scale in the early Neolithic. This was linked with the adoption of a settled way of life by the population, which in turn is indicated by the large number of pig remains found in the area of settlements, and the absence or insignificant presence of such remains on archaeological sites of other kinds (Zeuner, 1963). This provides indirect evidence that pig-keeping was connected with agrarian/stock-breeding rather than pastoral cultures.

The significance of the genus Sus for the development of material culture has long been widely recognised. There is evidence that in prehistoric times and even in the modern period, pigs were not only a source of valuable meat and fat, but were also sacrificial animals (Zeuner, 1963; Bökönyi, 1983), provided assistance in gathering activities 
and primitive agro-technical operations (Zeuner, loc. cit.), and even furnished entertainment (Cram, 1979).

Archaeozoological research into remains of the genus Sus, as in the case of other animals, has made it possible to reconstruct the changes that took place in the skeleton with the passage of time. The absence of clear descriptive differences between the bones of domestic pigs and wild pigs makes even the initial segregation of excavated material into the two forms very difficult. The majority of authors make use of fairly arbitrarily established differences of size, while making the reservation that remains classified as those of domestic pigs may contain some remains of wild pigs, and vice versa. Teichert (1969) amassed a considerable amount of data on the greatest length of bones of domesticated and wild pigs. He also established corresponding ranges of dimensions for both forms. This has provided a basis for greater objectivuty in determining whether a given excavated bone comes from a domestic or wild pig. Unfortunately bones of these animals preserved in a state which permits measurement of the greatest length occur only very rarely in archaeozoological materials. This limits the opportunities available of making use of the research results of this author in differentiating the bones of domestic from those of wild pigs.

The bones of animals, particularly those of domesticated animals, were subject to change over time. These changes occurred in both their dimensions and proportions. The direction and tempo of these changes vary for different species (Driesch, 1983). To date, the evolution of the skeleton of domesticated cattle (Lasota-Moskalewska, 1980) and of horses (Kobryń, 1981) has been investigated for Polish territory.

The aim of the present study has been to determine the changes in time that occurred in the skeleton and withers height of domestic and wild pigs, and also to attempt to correlate these changes with changes in the conditions of life of the wild and domesticated forms. The research has covered the magnitude and tempo of changes from the stone age in the Neolithic to the iron age in the Middle Ages (a period of about 5000 years). A further aim has been to establish criteria for evaluation which would make it possible to differentiate between the bones of domestic and wild pigs on the basis of breadth measurements.

\section{MATERIAL}

The material used consists in the dimensions of the bones of domestic and wild pigs from excavations, taken both from our own data and from literature published up to and including 1984 (Table 1). The measurement technique employed in the earlier studies was taken from Duerst (1926), and in the later 
Table 1

List of archaeological sites in Poland from which material has been used in this study.

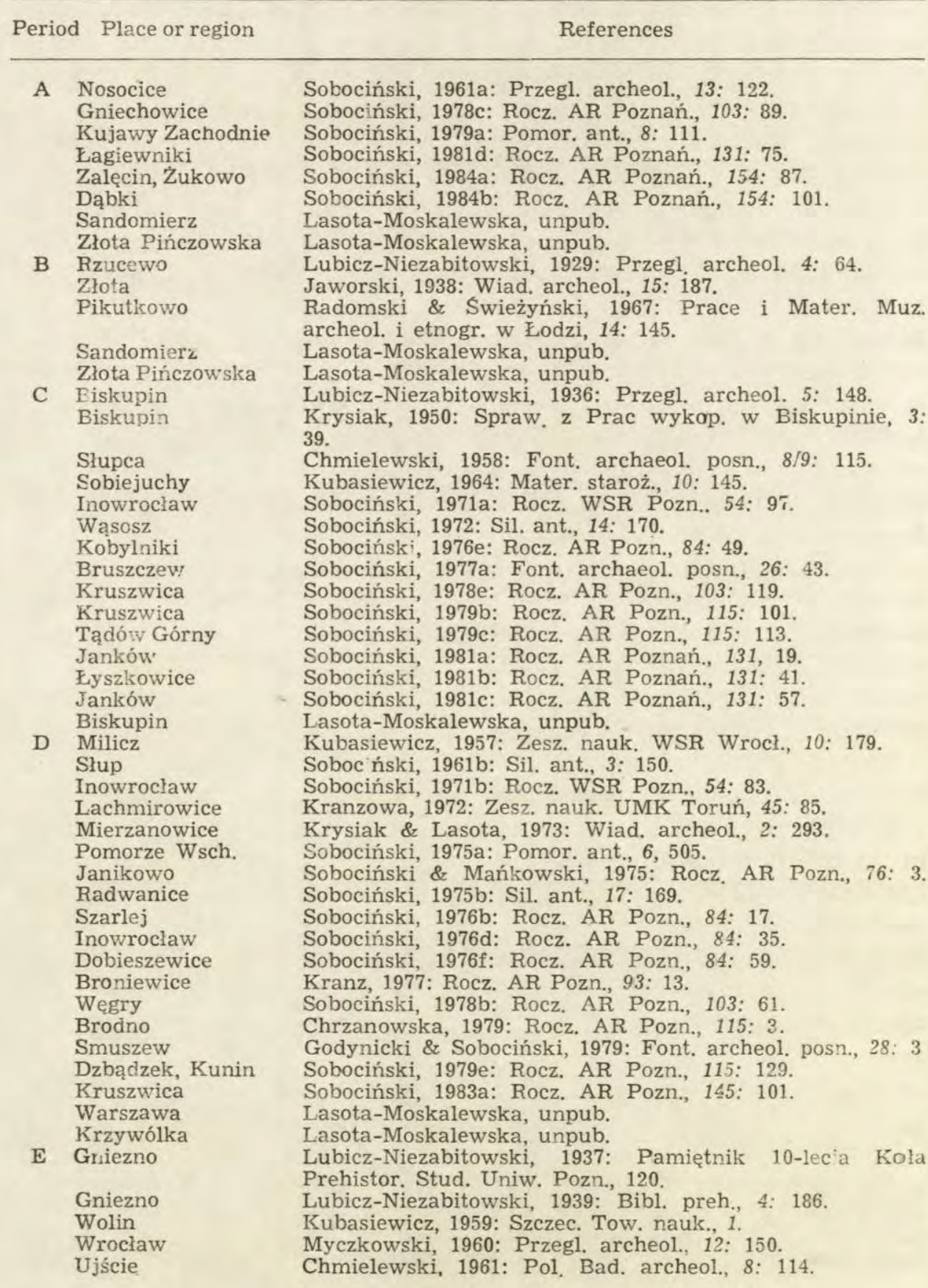


Sieradz

Bonikowo

Kruszwica

Radacz

Kedrzyn

Sąsiadka

Wiślica

Swiecie n. Wisłą

Szczecin

Szczecin

Ryczyn

Wloclawek

Gniezno

Kruszwica

Kaszów

Inowroclaw

Inowrocław

Gniezno

Jez. Wiecborskie

Opole, Wrocław

Uiście

Nakło n. Notecia

Bnin

Zukowice

Stary Zamek

Gdańsk

Gwieździna

Prodnica

Poznań

Opole

Kruszwica

Wegry

Czluchów

Zlotów

Mietlica

Kruszwica

Skeczniew

Santok

Wvsocz. Krajeńska

Jedwabno

Kałdus

Człuchów

Legnica

Słupsk

Wroclaw

Mietlica

Mietlica, Złotów

Santok

Kalisz

nnole

Ciechanów

Flbląg

Iłża

Krzesk

Łęczyca

Niewiadoma
Kubasiewicz, 1963: Prace i Mater. Muz. archeol, i etnogr. w Łodzi, 9: 195.

Sobociński, 1963: Prace Kom. archeol., 2: 3.

Sobociński, 1964: Rocz. WSR Pozn., 22: 173.

Schramm \& Gedymin, 1965: Rocz. WSR Pozn., 25: 185.

Wyrost, 1965: Przegl. zool., 9: 301.

Krysiak, 1966: Swiatowit, 27: 171.

Sobociński, 1967: Rocz, WSR Pozn., 36: 175.

Sobociński, 1968: Pomor. ant., 2: 321.

Gawlikowski, 1969: Mater. zach.-pomor., 15: 243.

Kubasiewicz \& Gawlikowski, 1969: Mater. zach.-pomor., 15: 189 .

Sobociński, 1969a: [In: "Wczesnośredniow, grodziska ryczyńskie na Sląsku”. J. Kramarek ed.].

Sobociński, 1969b: Zesz, nauk. UMK Toruń, 33: 135.

Sobociński \& Schramm, 1972: Zesz. nauk. UMK Torun, 45: 163.

Schramm, 1973: Rocz. AR Pozn., 60: 21.

Soboc'ński, 1973a: Sil. ant., 15: 249.

Sobociński, 1973b: Rocz. AR Pozn., 60: 81.

Sobociński, 1973c: Rocz. AR Pozn., 60: 63.

Schramm, 1974a: Acta Univ. N. Coper., 60: 259.

Schramm, 1974b: Acta Univ. N. Coper., 60: 275.

Chrzanowska \& Pospieszny, 1975: Zool pol., 24: 327.

Sobociński, 1975c: Rocz. AR Pozn., 76: 35.

Sobociński \& Godynicki, 1975: Rocz. AR Pozn., 75: 107. Sobociński, 1976a: [In: "Materiały do studiów nad osadnictwem bnińskim"'. PWN, 9: 121.

Sobociński, 1976c: Rocz. AR Pozn., 84: 27.

Chrzanowska, 1977: Rocz. AR Pozn., 93: 3.

Kubasiewicz, 1977: Prace Kom archeol., 9: 1.

Sobociński, 1977b: Rocz, AR Pozn., 93: 63.

Sobociński, 1977c: Rocz. AR Pozn., 93: 81.

Sobociński, 1977d: [In: "Początki i rozwój Starego Miasta w Poznaniu"]. PWN, 219.

Chrzanowska \& Molenda, 1978: Rocz. AR Pozn., 103: 3. Sobociński, 1978d: Rocz. AR Pbzn., 103: 109.

Sobociński, 1978a: Rocz AR Pozn., 103: 61.

Janaszek, 1979: Rocz. AR Pozn., 115: 9.

Janaszek \& Sobociński, 1979: Koszal. Zesz. muzeal., 9: 47.

Jernigan \& Sobociński, 1979: Rocz. AR Pozn., 115: 37. Schramm, 1979: Rocz. AR Pozn., 115: 89.

Sobociński, 1979d: Rocz. AR Pozn,, 115: 121.

Sobociński, 1979f: Rocz. AR Pozn., 115: 143.

Sobociński, 1980a: Rocz. AR Pozn., 121: 39.

Sobociński, 1980b: Rocz: AR Pozn., 121: 57.

Sobociński, 1980c: Rocz, AR Pozn, 121: 79.

Sobociński, 1980d: Rocz. AR Pozn., 121: 113.

Wyrost et al., 1980: Zool. pol., 27: 587.

Janaszek, 1981: Rocz. AR Pozn., 115: 19.

Wyrost \& Chrzanowska, 1981: Rocz. AR Pozn., 131: 163.

Jernigan \& Sobociński, 1983a: Rocz. AR Pozn., 145: 43.

Jernigan \& Sobociński, 1983b: Rocz. AR Pozn., 145: 69.

Sobociński, 1983b: Rocz. AR Pozn., 145: 119.

Kobryń \& Serwatka, 1984: Archeol. Pol., 29: 415.

Molenda, 1984: Rocz. AR Pozn., 154: 67.

Lasota-Moskalewska, unpub.

$$
\text { ", }
$$


Pelezyska

Plock

Pultusk

Piotrków Tryb.

Radom

Smogulec

Tykocin

Warszawa

Wyszogró

Żerniki
Lasota-Moskalewska, unpub.

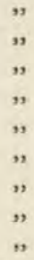

A - from 3500 to 2500 years BC, B - flom 2500 to 1500 years BC, C - from 1500 to 500 years $\mathrm{BC}$, D - from 500 years $\mathrm{BC}$ to 500 years $\mathrm{AD}, \mathrm{E}$ - from 500 to 1500 years $A D$.

ones from Driesch (1976). In the case of the measurements which we deal with here, the two techniques do not differ.

The results of measurement which were most commonly used by the authors were selected for analysis. These were the following characteristics: scapula smallest length of the collum (SLC); humerus - breadth of the distal end (HBD), breadth of the trochlea (HBT); radius - breadth of the proximal end (RBP); tibia - breadth of the distal end (TBD); talus - greatest height (TGH); calcaneus - greatest length (CGL). Abbreviations of the names of dimensions taken from Driesch (1976) will be used in the further parts of the study. The ratio of the breadth of the trochlea to the breadth of the distal end of the humerus has also been calculated and analyzed $(\mathrm{HBT} \times 100): \mathrm{HBD}$. The height in the withers has also been determined (HW), using the coefficients given by Teichert (1969). In establishing this, the height of the talus and length of the calcaneus have been used, as well as all the available dimensions of the greatest length of the limb bones.

It has proved that many of the dimensions attributed to domestic or wild pigs are questionable. It is generally known that all the bones of a domestic pig are smaller and more delicate than those of a wild pig. This is one of the basic morphological effects of domestication (Bogolubski, 1968). But when we are dealing with a single bone, or, as more frequently happens, only a small fragment of a single bone, it is difficult to avoid subjectivity in evaluation. It was for this reason that we decided that in general we would not make use of original information on this, but carry out our own classification into groups: the domestic pig, the wild pig and the transitional form on the basis of the principles described below.

The whole material was divided into five chronological periods of a millennium (Table 1). The time divisions of these periods are in accordance with the system applied in earlier studies on the evolution of the skeleton of domestic cattle (Lasota-Moskalewska, 1980) and horses (Kobryń, 1984).

\section{METHODS}

In order to carry out an objective division of the data into those characteristic of the domestic or wild pig, the frequency distributions of all the examined characteristics were analysed. When a bi-modal curve was obtained it was treated as a reflection of distribution of characteristics in material composed from two populations. It was then established whether curves corresponding to two pop- 
ulations have tangential points, and if so, over what range of magnitude, Empirical curves were equalized freehand to ensure that they characterised populations and not merely random samples. Next, the range of variability of each characteristic was noted: the lower corresponding to domestic pigs and the higher to wild pigs. Ranges of variability lying in places where the two curves overlapped, or between the curves, were considered to correspond to the transitional form between
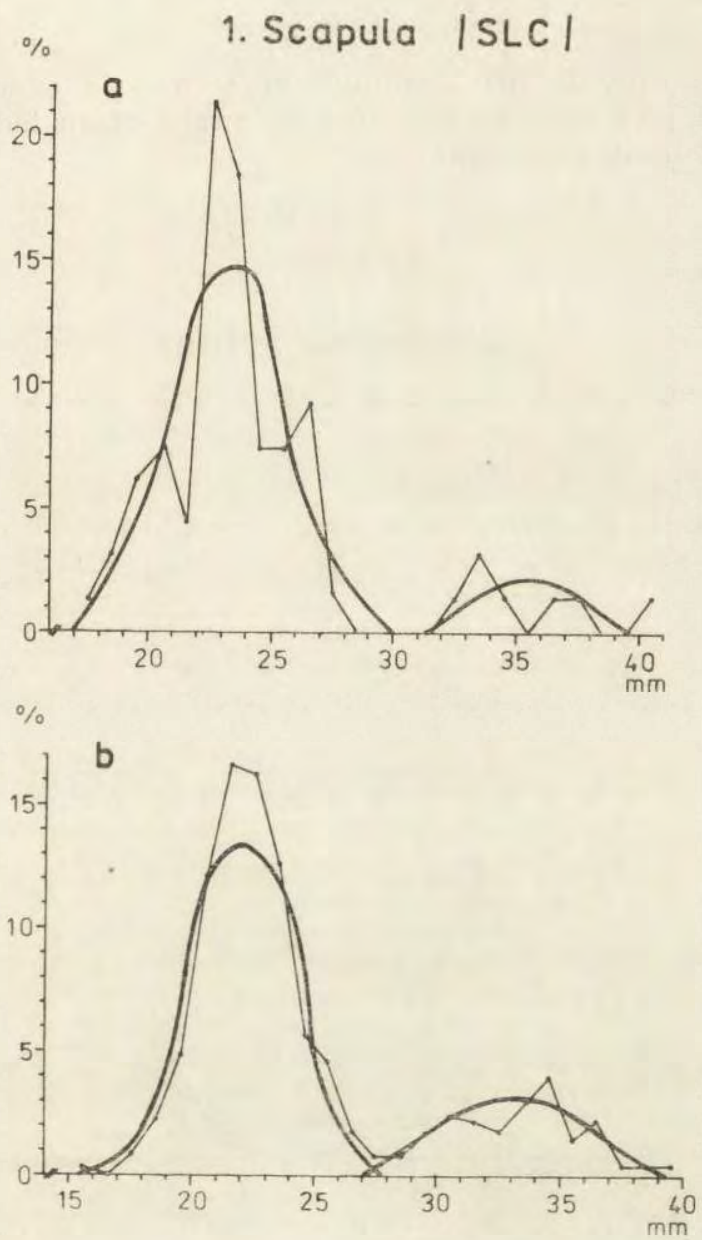

Fig. 1. Frequency distribution of bone dimensions and height in the withers of domestic and wild pigs from Polish territory $(\mathrm{a}-$ chronological periods $\mathrm{A}+\mathrm{B}+\mathrm{C}+\mathrm{D}$; b - chronological period E). Symbols given in the text. Figure completed on pages $58-62$.

the wild and domestic pig. In order to make the distributions clearer, the analysis described above was carried out separately for early mediaeval and mediaeval materials (period E) and for the whole group of earlier materials (periods $\mathrm{A}+\mathrm{B}+$ $\mathrm{C}+\mathrm{D})$. 
In each of the periods mentioned, changes in the average dimensions over time were examined. Changes in time from the Neolithic (periods A and B) to the Middle Ages (period E) were evaluated on the basis of the difference between the averages characteristic of these chronological periods, normalized to a value in Neolithic according to the following formula:

$$
\frac{\bar{x}_{(\mathrm{A}+\mathrm{B})}-\bar{x}_{\mathrm{E}}}{\bar{x}_{(\mathrm{A}+\mathrm{B})}} \times 100
$$

The differences between the magnitude of each bone dimension in domestic pigs $(d)$ and wild pigs $(w)$ was evaluated by means of an index of dimorphism, according to the following formula:

$$
\frac{2\left(\bar{x}_{w}-\bar{x}_{d}\right)}{\bar{x}_{w}+\bar{x}_{d}}
$$
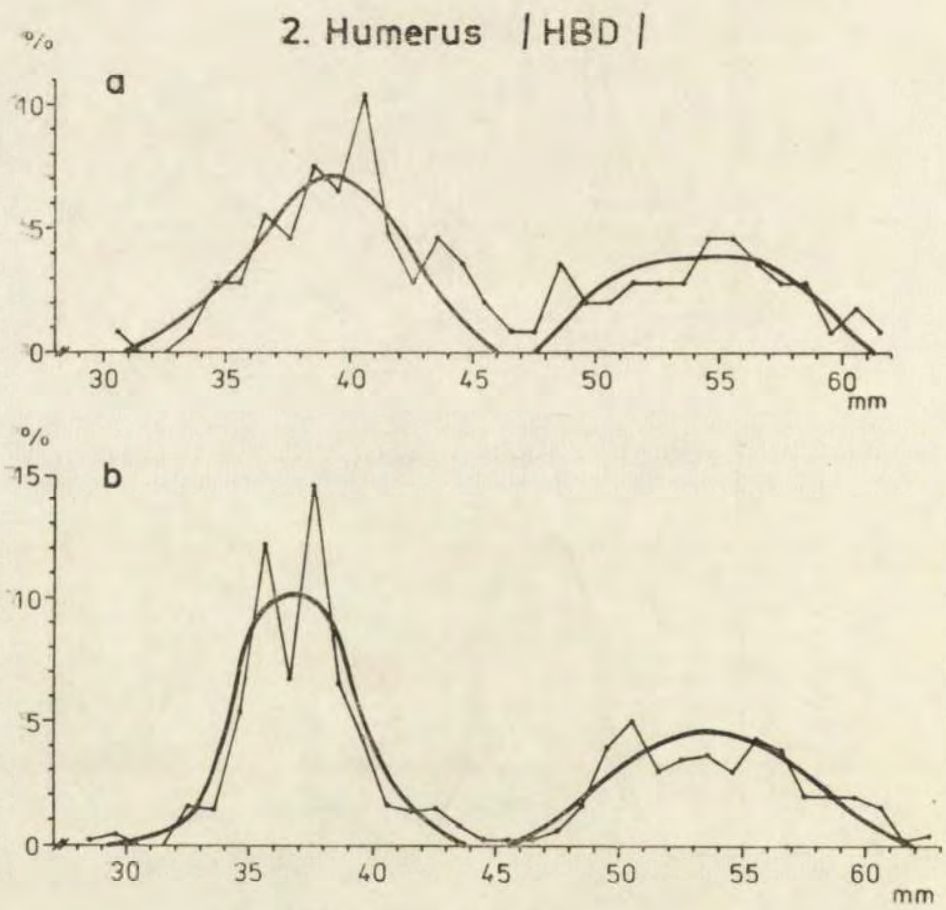

Fig. 1. continued.

In order to make possible simultaneous evaluation of the magnitude of differently denominated characteristics, and to facilitate the identification of bones from domestic or wild pigs on the basis of certain dimensions, a point score method was adopted which is described in detail below.

On the basis of the largest quantity of material, from the early mediaeval and mediaeval period (period E), we have sought to determine whether there were geographical differences over Polish territory in the size of domestic and wild pigs. An arbitrary and schematic division of the area of Poland into North, 
South, East and West was adopted. The Northern area was divided from the Southern between the 51st and 52nd parallel of latitude, at the level of the cities of Radom, Piotrków Trybunalski and Lubin; the Eastern and Western areas were divided by the 19th line of longitude.

\section{RESULTS}

\section{The Range of Variability of Characteristies}

All the curves dealing with absolute dimensions and height in the withers were clearly bi-modal, which made it possible to distinguish two separate frequency distributions, which usually had tangential points or even overlapped (Fig. 1).
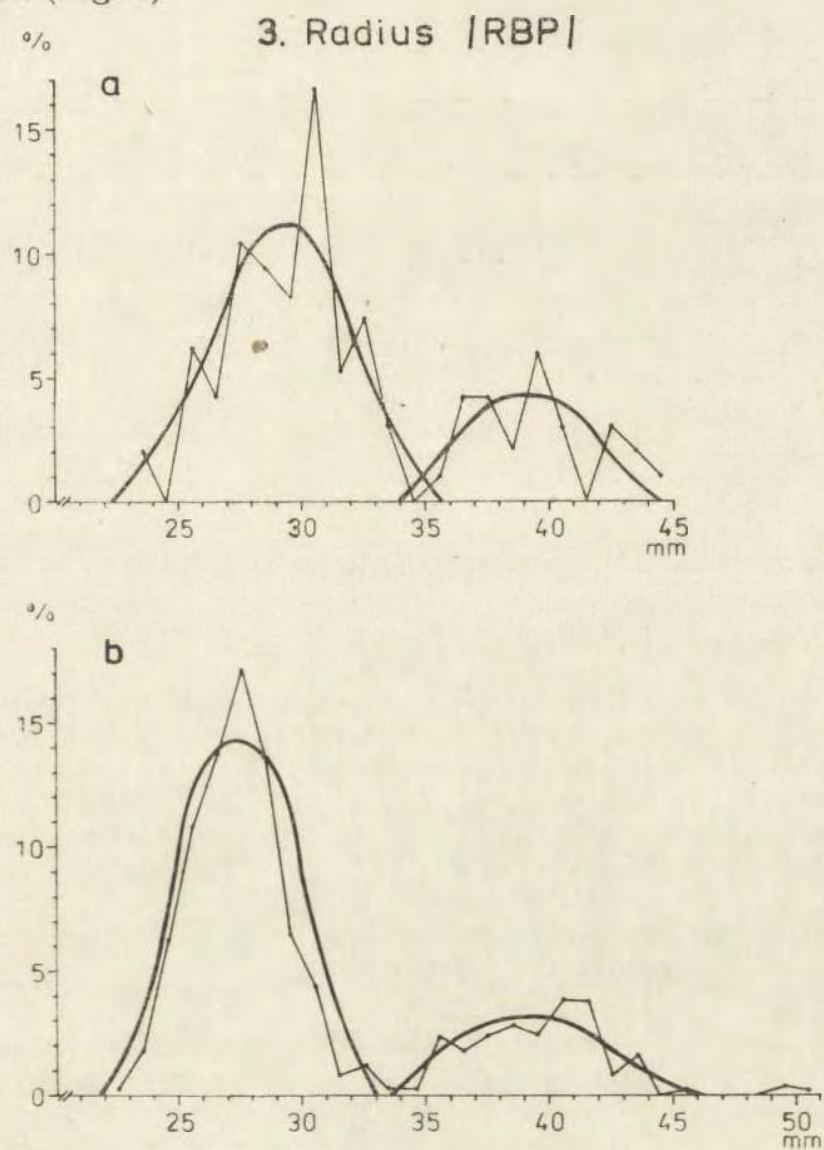

Fig. 1. continued.

It should be emphasized that in the early mediaeval and mediaeval materials, the range of variability of the transitional form was considerably lower than in the material dating from earlier periods. The 

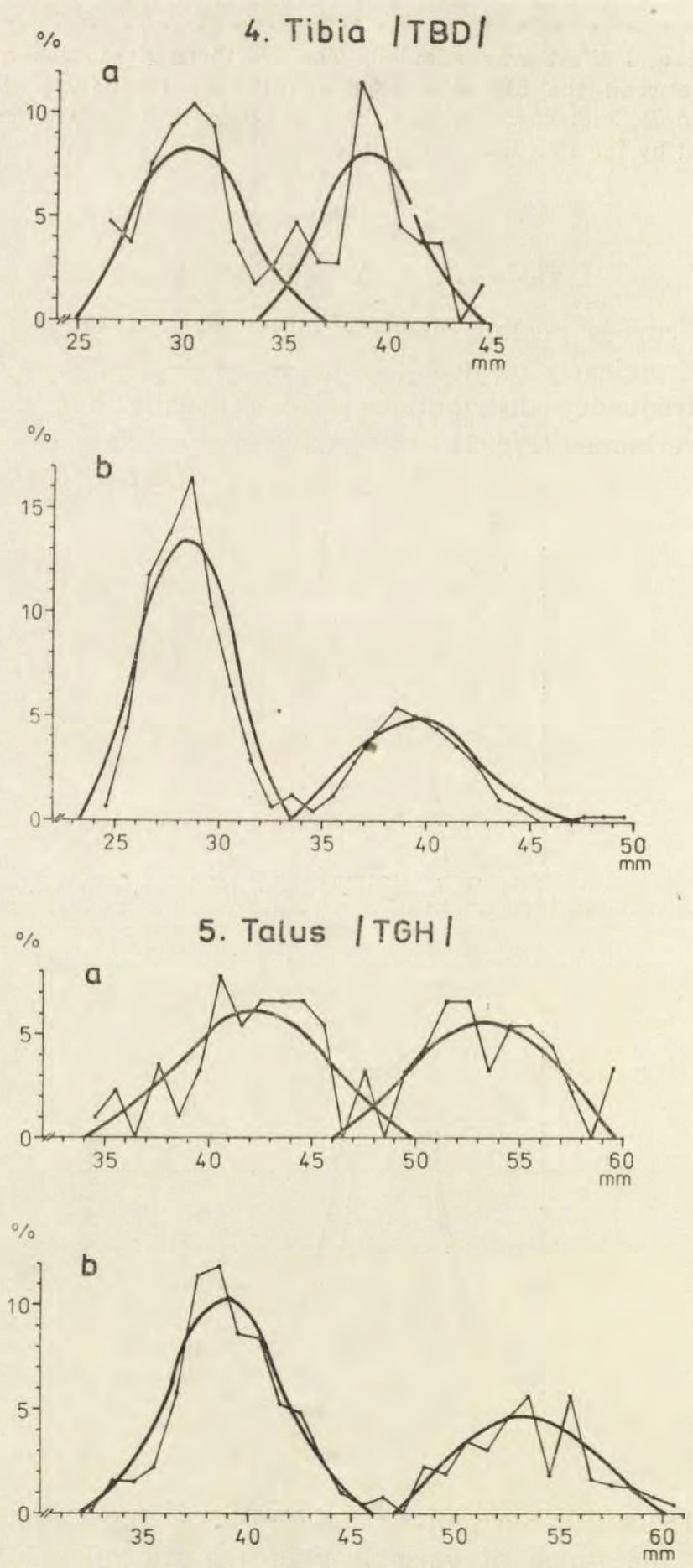

Fig. 1. continued. 
Size of pigs from Neolithic to M.ddle Ages
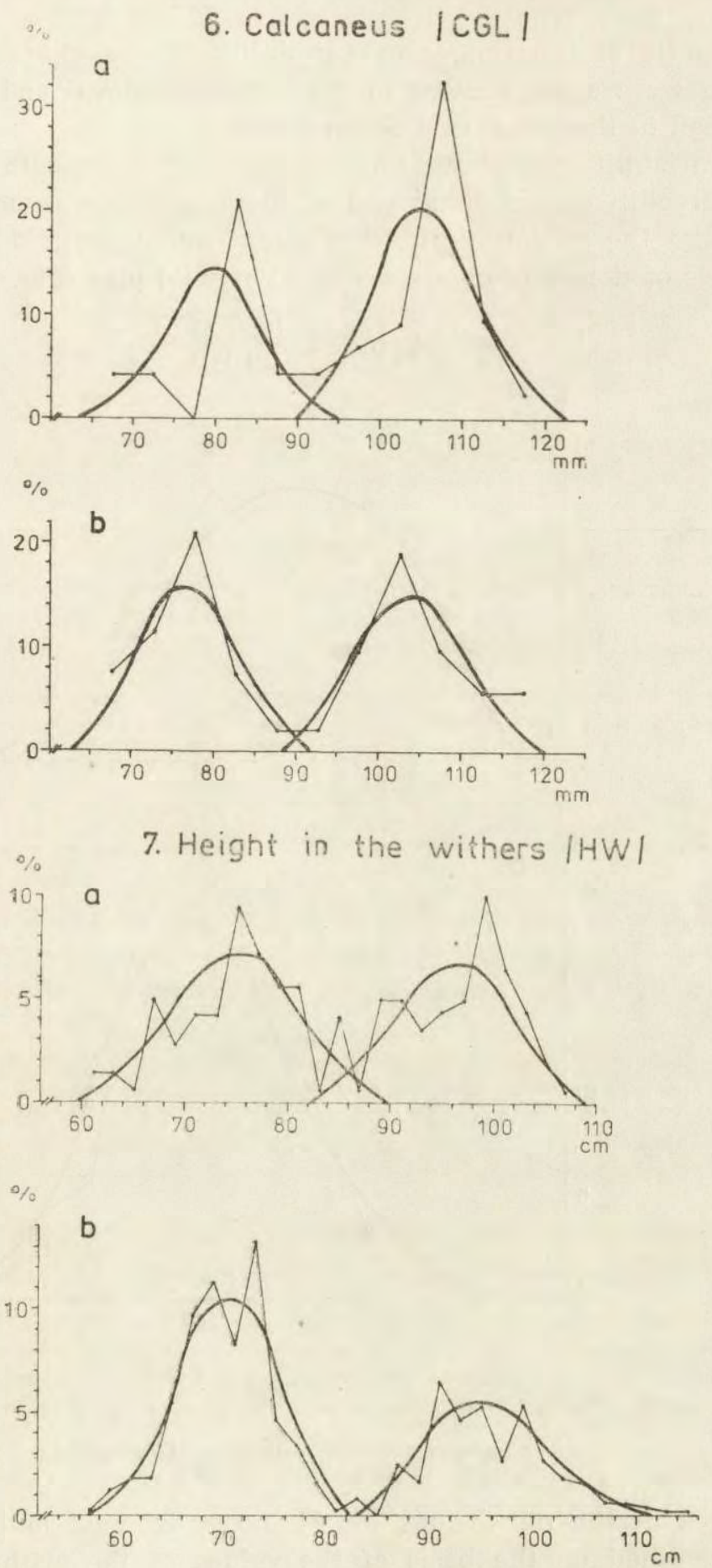

Fig. 1. continued. 
lower limits of the ranges of variability of the characteristics of the wild pig were always lower in the early mediaeval and mediaeval material than in that from earlier periods.

The variability distribution of the ratio of the breadth of the trochlea to the breadth of the distal end of the humerus was uni-modal, which shows that the magnitude of this index cannot be used to differentiate the bones of domestic pigs from those of wild pigs (Fig. 1, 8).
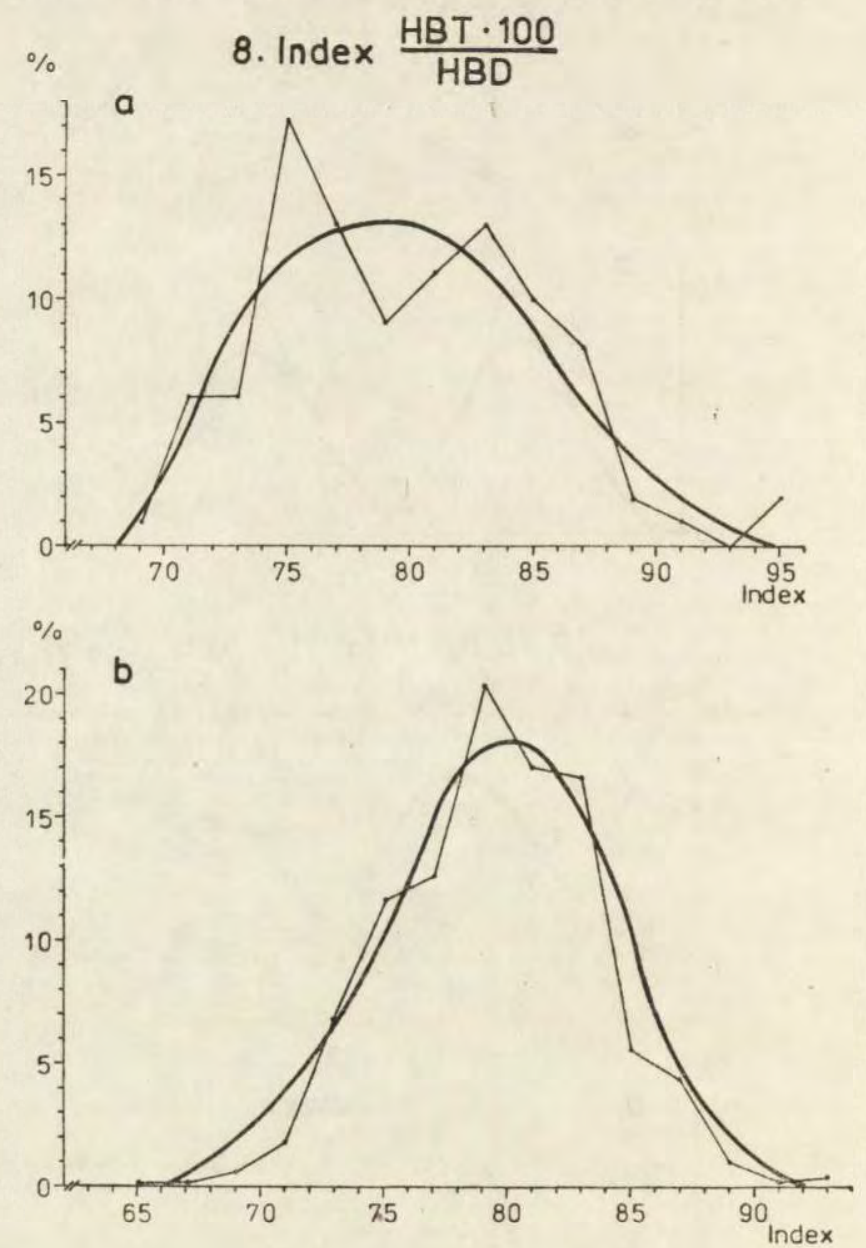

Fig. 1. concluded.

2. Changes over Time in Bone Dimensions

Changes in the dimensions of the bones of wild and domestic pigs were examined on the basis of the values of the arithmetic mean of these dimensions in particular millennia (Table 2, Fig. 2). When there 
Table 2

Arithmetic mean $(\bar{x})$, standard deviation (SD), coefficient of variability (CV) of bone $(\mathrm{mm})$ and height in the withers $(\mathrm{cm})$ of domestic and wild pigs from. Polish territory.

\begin{tabular}{|c|c|c|c|c|c|c|c|c|}
\hline \multirow{2}{*}{ Dimension $^{1}$} & \multicolumn{4}{|c|}{ Domestic pig } & \multicolumn{4}{|c|}{ Wild pig } \\
\hline & $\bar{x}$ & SD & $\mathrm{CV}$ & $n$ & $\bar{x}$ & SD & $\mathrm{CV}$ & $n$ \\
\hline \multicolumn{9}{|c|}{ Period A (from 3500 to 2500 years BC) } \\
\hline SLC & 22.7 & 2.5 & 11.0 & 15 & 34.5 & - & 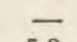 & \\
\hline HBD & 38.1 & 3.2 & 8.4 & 10 & 56.7 & 3.0 & 5.3 & 3 \\
\hline RBP & 29.0 & 1.4 & 4.8 & 4 & 39.0 . & - & - & 1 \\
\hline TBD & 29.8 & 1.7 & 5.7 & 4 & 39.5 & 一 & - & 2 \\
\hline TGH & 42.9 & 1.6 & 3.7 & 9 & 52.0 & - & $\overline{0}$ & 2 \\
\hline CGL & 80.5 & - & - & 2 & 104.5 & 6.2 & 5.9 & 4 \\
\hline HW & 76.5 & 2,7 & 3.5 & 11 & 98.5 & 4.3 & 4.4 & 4 \\
\hline \multicolumn{9}{|c|}{ Period B (from 2500 to 1500 years BC) } \\
\hline SLC & 24.0 & - & - & 1 & - & - & - & - \\
\hline HBD & 38.5 & 2.1 & 5.4 & 6 & - & - & - & - \\
\hline RBP & 28.0 & - & - & 1 & - & - & - & - \\
\hline TBD & 27.5 & 5.2 & 18.9 & 4 & - & - & - & $\overline{1}$ \\
\hline TGH & 40.6 & 3.1 & 7.6 & 10 & 52.0 & - & - & 1 \\
\hline CGL & 82.0 & 3.5 & 4.3 & 3 & - & - & - & $\overline{1}$ \\
\hline HW & 74.0 & 5.3 & 7.2 & 14 & 93.1 & - & - & 1 \\
\hline \multicolumn{9}{|c|}{ Period A+B (from 3500 to 1500 years BC) } \\
\hline SLC & 22.8 & 2.4 & 10.5 & 16 & 34.5 & - & - & 2 \\
\hline HBD & 38.2 & 2.8 & 7.3 & 16 & 56.7 & - & - & 3 \\
\hline RBP & 28.8 & 2.0 & 7.0 & 8 & 39.5 & - & - & 2 \\
\hline TBD & 28.6 & 2.0 & 7.0 & 8 & 39.5 & - & - & 2 \\
\hline TGH & 41.7 & 2.7 & 6.5 & 19 & 52.0 & - & $-\overline{0}$ & 3 \\
\hline CGL & 81.4 & 2.6 & 3.2 & 5 & 104.5 & 6.2. & 5.9 & 4 \\
\hline HW & 75.1 & 4.4 & 5.8 & 25 & 97.4 & 4.5 & 4.6 & 5 \\
\hline \multicolumn{9}{|c|}{ Period C (from 1500 to 500 years BC). } \\
\hline SLC & 28.8 & 2.5 & 8.7 & 16 & 36.0 & 3.2 & 8.9 & 4 \\
\hline HBD & 40.0 & 3.6 & 9.0 & 20 & 55.5 & 3,4 & 6.1 & 23 \\
\hline RBP & 28.6 & 2.3 & 8.0 & 47 & 40.5 & 1.9 & 4.7 & 14 \\
\hline TBD & 29.9 & 1.6 & 5.4 & 30 & 39.6 & 1.7 & 4,3 & 30 \\
\hline TGH & 40.3 & 3.0 & 7.4 & 17 & 54.5 & 2.6 & 4.8 & 23 \\
\hline CGL & 79.0 & 7.8 & 9.9 & 5 & 106.3 & 3.6 & 3,4 & 11 \\
\hline HW & 73.0 & 5.6 & 7.7 & 25 & 97.9 & 4.3 & 4.4 & 35 \\
\hline \multicolumn{9}{|c|}{ Period D (from 500 years $\mathrm{BC}$ to 500 years $\mathrm{AD}$ ) } \\
\hline SLC & 22.1 & 2.1 & 9.5 & 26 & 36.0 & - & - & 1 \\
\hline HBD & 37.9 & 2.4 & 6.3 & 32 & 54.4 & 2.8 & 5.1 & 13 \\
\hline RBP & 29.0 & 2.8 & 9.6 & 18 & 39.0 & 2.6 & 6.7 & 7 \\
\hline TBD & 28.8 & 2.1 & 7.3 & 26 & 39.4 & 1.5 & 3.8 & 9 \\
\hline TGH & 40.8 & 2.8 & 6.7 & 17 & 53.6 & 1.8 & 3.3 & 12 \\
\hline CGL & 75.8 & 8.3 & 10.9 & 9 & 106.4 & 4.9 & 4.6 & 9 \\
\hline HW & 73.1 & 5.8 & 7.9 & 30 & 97.8 & 4.1 & 4.2 & 20 \\
\hline \multicolumn{9}{|c|}{ Period E (from 500 to 1500 years $A D$ ) } \\
\hline SLC & 21.7 & 1.9 & 8.8 & 286 & 33.0 & 2.6 & 7.9 & 82 \\
\hline HBD & 36.5 & 6.0 & 16.4 & 297 & 53.3 & 3.6 & 6.8 & 211 \\
\hline RBP & 26.8 & 1.9 & 7.1 & 333 & 39.1 & 6.2 & 15.8 & 102 \\
\hline TBD & 27.8 & 1.7 & 6.1 & 316 & 39.1 & 2.5 & 6.4 & 148 \\
\hline TGH & 38.6 & 2.5 & 6.5 & 241 & 52.9 & 2.8 & 5.3 & 126 \\
\hline CGL & 73.6 & 4.1 & 5.6 & 21 & 103.8 & 7.4 & 7.1 & 32 \\
\hline HW & 69.1 & 4.4 & 6.4 & 278 & 95.3 & 6.2 & 6.5 & 168 \\
\hline
\end{tabular}

1 See text, p. 56 for definitions of dimensions. 
were exceptionally few data, which was the case in the earliest periods (A and B), the mean was calculated in common for two millennia, and the result was treated as characteristic of the whole Neolithic.

The changes that occurred in the bones of dcmestic pigs were not entirely uniform (Fig. 2). The only regularity that can be observed was
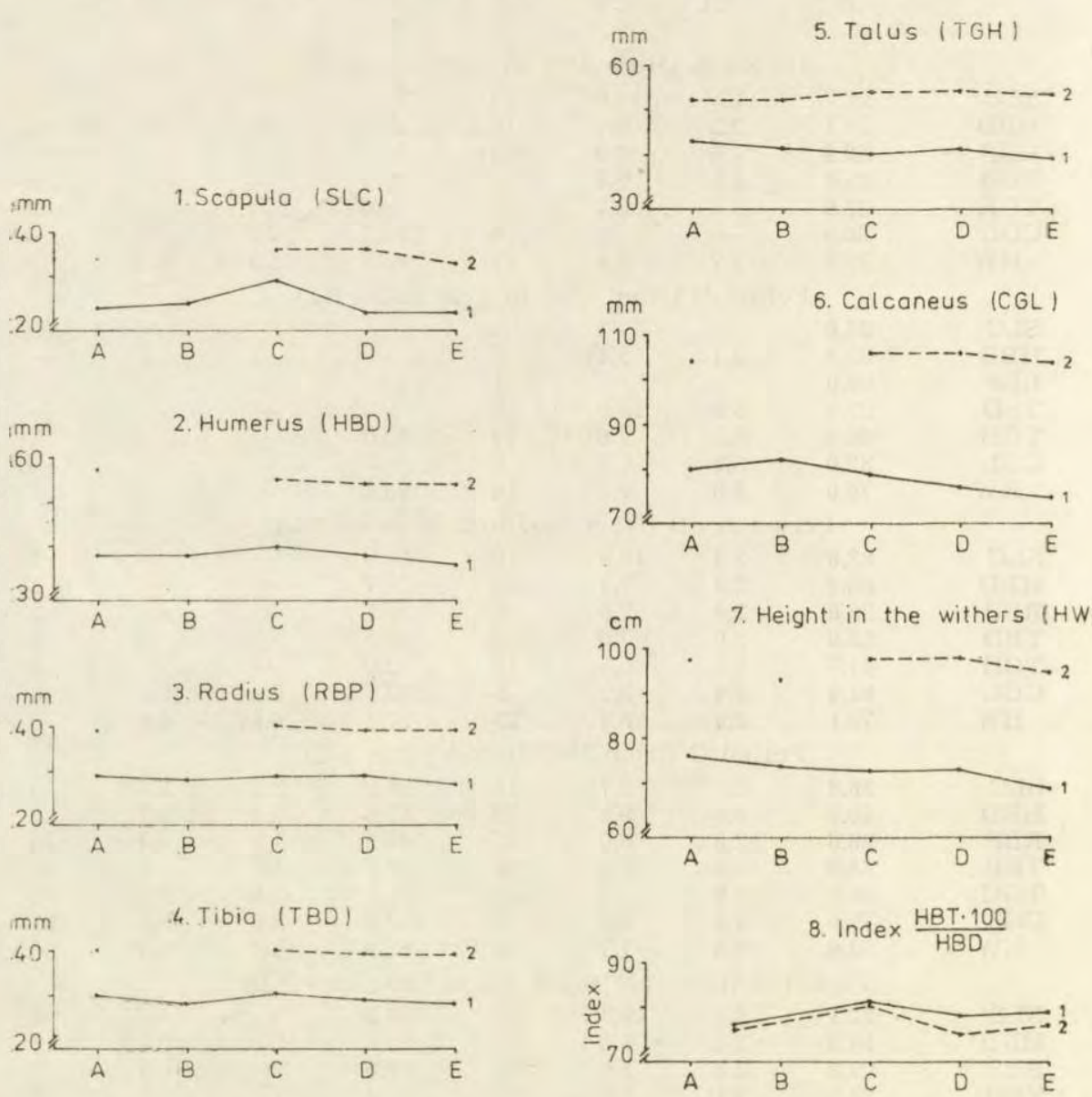

Fig. 2. Changes in the arithmetic means of values of bone dimensions and height in the withers in domestic pigs (1) and wild pigs (2) from Polish territory from the Neolithic to the Middle Ages (chronological periods A, B, C, D, E). Symbols given in the text.

a reduction in the average dimensions of bones in the early mediaeval and mediaeval period (period E) in comparison with the average dimensions in the early iron age (period D).

In order to discover the secular trend, the arithmetic mean of size. for the whole Neolithic was compared with that for the early mediaeval 
and mediaeval period (Table 2). In order to attain conditions of comparability, absolute differences were normalized to initial sizes according to formula 1 , and given in percentages (Table 3). This comparison showed that the breadth of the distal end of the tibia diminished least; the breadth of the distal end of the humerus and the length of the scapula collum were reduced to a somewhat greater extent; the breadth of the proximal end of the radius and height of the talus were more greatly reduced; and the length of the calcaneus had diminished to the greatest extent.

Because of the paucity of data available for periods A, B and C, it is not possible to define the nature of changes in bone dimensions in the case of wild pigs (Table 2, Fig. 2). It has only been observed that, as in the case of domestic pigs, there was a tendency to a reduction in almost all dimensions in the early mediaeval and mediaeval period (E) in comparison with the preceding period (period D).

\section{Table 3}

\begin{tabular}{|c|c|c|}
\hline Dimension & Domestic pig & Wild pig \\
\hline SLC & 4.8 & 4.3 \\
\hline HBD & 4.4 & 6.0 \\
\hline RBP & 6.9 & -0.3 \\
\hline TBD & 2.8 & 1.0 \\
\hline TGH & 7.4 & -1.7 \\
\hline CGL & 9.6 & 0.7 \\
\hline HW & 8.0 & 2.2 \\
\hline
\end{tabular}

Comparison of the normalized differences in dimensions in the wild pig indicates that in the period from the Neolithic to the middle ages, the breadth of the distal end of the humerus and the length of the scapula collum were most greatly diminished. The changes that occurred in other dimensions were insignificant (Table 3).

\section{Changes over Time in Height in the Withers}

The withers height of domestic pigs diminished systematically but not uniformly in each succeeding millennium (Table 2, Fig. 2). The changes were greater between the two earliest periods (A to B), and between the two latest (D to $\mathrm{E}$ ). In general, early mediaeval and mediaeval domestic pigs were $8 \%$ lower in the withers than in the Neolithic (Table 3) 
There is not a great deal of data on the withers height of wild pigs in the Neolithic (periods A and B), which makes it impossible to assess the changes in this characteristic. In the period from the bronze age (period C) to the early iron age (period D) height in the withers remained unchanged (Table 2, Fig. 2), but it did diminish in the early mediaeval and mediaeval periods (period E). In general the height in the withers of the wild pig fell by only $2.2 \%$ from the Neolithic to the Middle Ages (Table 3).

\section{Changes over Time in the Ratio of the Breadth of the Trochlea to the Breadth of the Distal End of the Humerus}

Although this index did not directly differentiate domestic from wild pigs, nonetheless, the magnitude of absolute dimensions provided the possibility of distinguishing the two forms. The arithmetic mean of the

Table 4

\begin{tabular}{|c|c|c|c|c|c|c|}
\hline \multicolumn{3}{|c|}{ Domestic pig } & \multicolumn{3}{|c|}{ Wild pig } & \multirow[t]{2}{*}{ Significance } \\
\hline $\bar{x}$ & $S D$ & $n$ & $\overline{\bar{x}}$ & $S D$ & $\bar{n}$ & \\
\hline \multicolumn{7}{|c|}{ Period $A+B$ (from 3500 to 1500 years $B C$ ) } \\
\hline 76.2 & 5.6 & 12 & 74.5 & 6.0 & 3 & NS \\
\hline \multicolumn{7}{|c|}{ Period C (from 1500 to 500 years BC) } \\
\hline 81.4 & 6.0 & 26 & 80.0 & 4.5 & 20 & NS \\
\hline \multicolumn{7}{|c|}{ Period D (from 500 years $\mathrm{BC}$ to 500 years $\mathrm{AD}$ ) } \\
\hline 78.5 & 5.1 & 26 & 73.8 & 3.4 & 12 & $\alpha=0.01$ \\
\hline \multicolumn{7}{|c|}{ Period E (from 500 to 1500 eyars AD) } \\
\hline 79.2 & 5.0 & 243 & 76.5 & 4.9 & 179 & $\alpha=0.001$ \\
\hline
\end{tabular}

value of this index indicated the trend of changes in time to be parallel for both forms, although the values are lower for the wild pig (Table 4, Fig. 2). There is a rising tendency for this index from the Neolithic to the Middle Ages. The greatest similarity between the magnitudes of the index for domestic pigs and wild pigs occurs in the Neolithic (periods A and B) and in the bronze age (period C). In later periods, the magnitudes of the index suggest substantially greater differences. The Student test showed these differences to be significant (in period D: $t=2.770>$ $>t_{\alpha}=0,01=2.750$ when $v=31$; in period E: $t=5.14>t_{\alpha}=0,01=2.576$ when $v=420)$. 


\section{Differences in the Size of Domestic and Wild Pigs}

Analysis of the development of differences between the sizes of these two forms was carried out on the basis of height in the withers, since the quantity of data was greatest for this. The differences were evaluated according to the index of dimorphism calculated according to formula 2.

With the passage of time, the difference between the height in the withers of domestic and wild pigs increased (Fig. 3). The differences were greatest in the earliest periods (from $\mathrm{A}+\mathrm{B}$ to $\mathrm{C}$ ) and in the latest (from $\mathrm{D}$ to $\mathrm{E}$ ). The magnitude of the differences remained unchanged between periods $\mathrm{C}$ and $\mathrm{D}$.

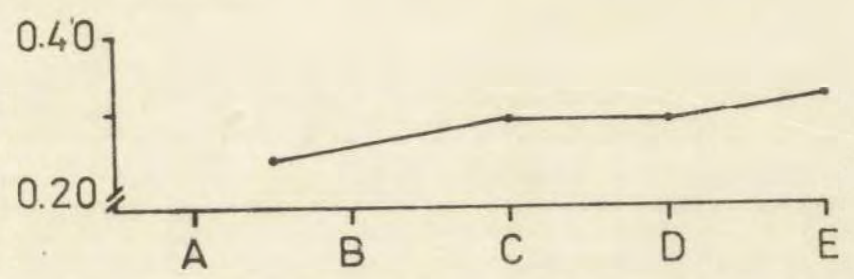

Fig. 3. Changes in value of the dimorphism index of height in the withers between domestic and wild pigs from Polish territory from the Neolithic to the Middle Ages (chronological periods - A, B, C, D, E). Symbols given in the text.

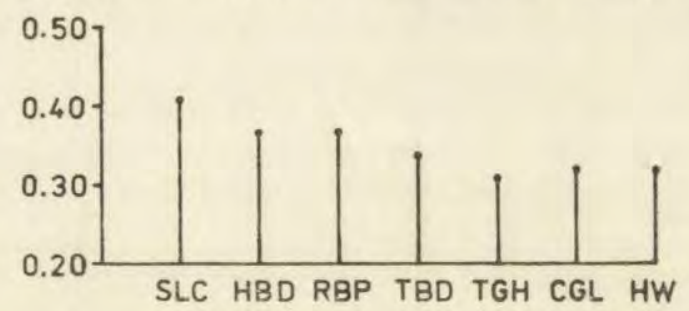

Fig. 4. Comparison of values of the dimorphism index between domestic and wild pigs from Polish territory in the early mediaeval and mediaeval period (period E). Symbols given in the text.

Because of the large quantity of data, it was possible for the early mediaeval and mediaeval period (period E), to analyse the comparative magnitude of index of dimorphism for all the examined characteristics (Fig. 4). The domestic and wild pig differed from each other in this period most greatly in length of the scapula collum. They differed somewhat less in the breadth of the distal end of the humerus and proximal end of the radius. Smaller differences are found in the case of breadth of the distal end of the tibia, length of the calcaneus, and height of the talus. These two last characteristics differentiate domestic and wild pigs in almost an identical way to height in the withers. 


\section{Characteristics of Domestic and Wild Pigs in Point Score Evaluation}

A point score method was used to facilitate evaluation of the magnitudes of particular bone dimensions and height in the withers; this method had already earlier been applied in archaeozoology to evaluate the dimensions of bones of domesticated cattle (Lasota-Moskalewska, 1984). It consists in the transposition of variously denominated dimensions (in millimetres and centimetres) and also dimensions of various orders of magnitude onto a common abstract scale. This scale contains 100 points (Fig. 5). Point 0 was taken to be the smallest dimension of a given characteristic in domestic pigs, and 100 points to be the greatest dimension of the same given characteristic in wild pigs.
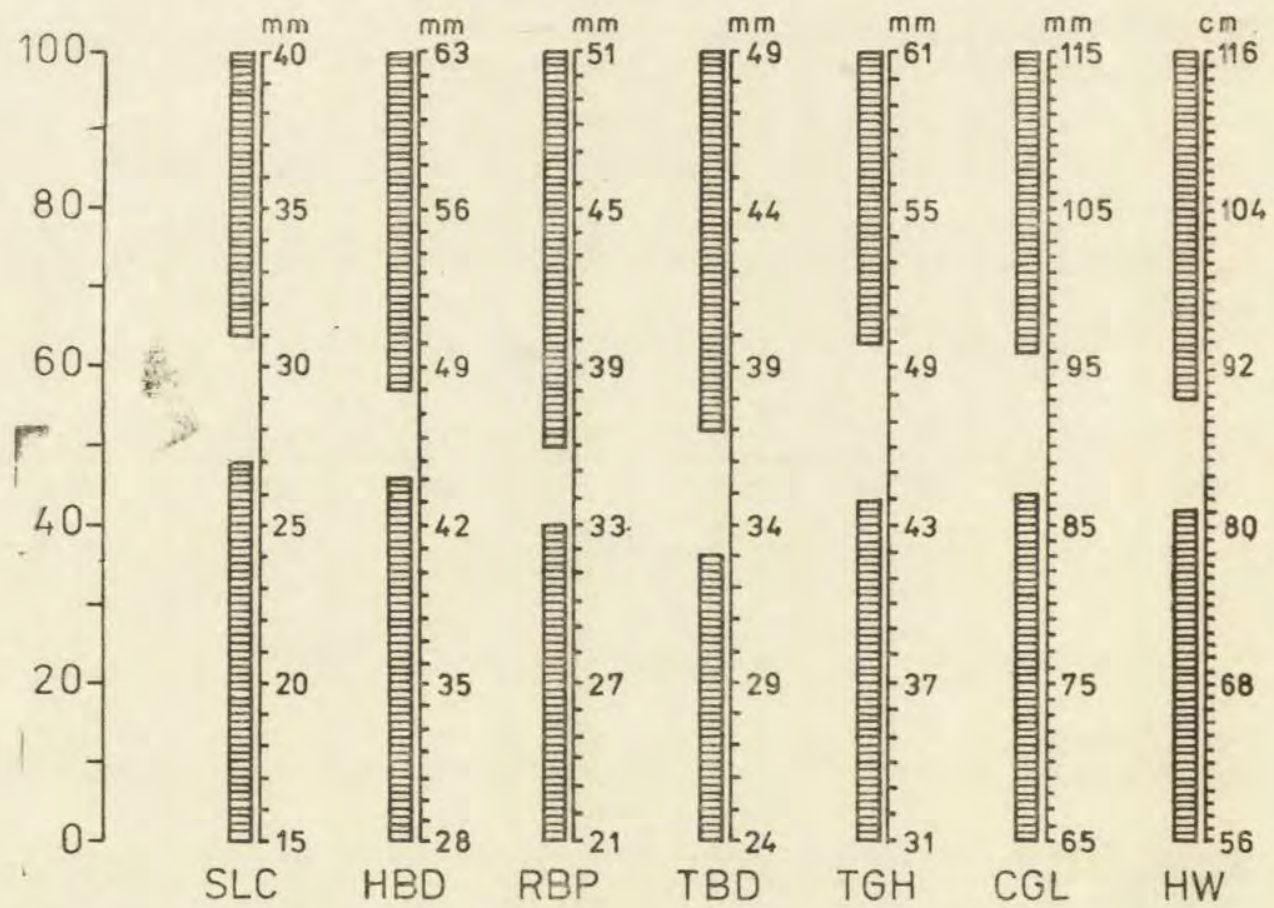

Fig. 5. Points $(0-100)$ and the corresponding absolute values of bone dimensions and the withers height of domestic pigs (lower hatched fields) and wild pigs (upper hatched fields) from Polish territory. Symbols given in the text.

\section{Geographical Variability}

Geographical variability was determined by using the point score method (Fig. 5). Comparison of average sizes obtained for domestic pigs kept in Eastern and Western Poland shows that they were practically 
identical (Table 5). A high degree of similarity was also attested in the size of pigs kept in Northern and Southern Poland.

Analogous comparison for wild pigs was carried out only on the basis of height in the withers, because of the incomplete data available on other characteristics. The average height of wild pigs living in the early mediaeval and mediaeval period (period E) in Eastern and Western

Table 5

Arithmetic mean $(\bar{x})$, standard deviation (SD), coefficient of variability $(\mathrm{CV})$ of bone dimensions $(\mathrm{mm})$ and height in the withers $(\mathrm{cm})$ and their corresponding points (in brackets) of domestic pigs from various geographical regions of Poland.

\begin{tabular}{|c|c|c|c|c|}
\hline Dimension & $\bar{x}$ & $\mathrm{SD}$ & $\mathrm{CV}$ & $n$ \\
\hline \multicolumn{5}{|c|}{ East } \\
\hline SLC & $21.2(25)$ & 2.5 & 11.8 & 43 \\
\hline HBD & $36.5(24)$ & 2.3 & 6.3 & 114 \\
\hline RBP & 26.7 (19) & 2.2 & 8.2 & 77 \\
\hline TBD & $27.8(23)$ & 2.0 & 7.2 & 128 \\
\hline TGH & 38.9 (23) & 2.6 & 6.7 & 55 \\
\hline CGL & $75.5(20)$ & - & - & 2 \\
\hline HW & $69.8(23)$ & 4.6 & 6.6 & 58 \\
\hline \multicolumn{5}{|c|}{ West } \\
\hline SLC & $21.7(26)$ & 1.8 & 8.3 & 243 \\
\hline HBD & $36.6(24)$ & 2.4 & 6.6 & 183 \\
\hline RBP & 27.1 (20) & 2.1 & 7.7 & 256 \\
\hline TBD & 27.9 (23) & 1.6 & 5.7 & 188 \\
\hline TGH & $37.8(22)$ & 2.3 & 6.1 & 186 \\
\hline CGL & 73.8 (18) & 4.6 & 6.2 & 21 \\
\hline HW & $69.5(23)$ & 4.8 & 6.9 & 220 \\
\hline \multicolumn{5}{|c|}{ South } \\
\hline SLC & $21.5(26)$ & 1.7 & 7.9 & 26 \\
\hline HBD & 35.8 (22) & 3.6 & 10.0 & 28 \\
\hline $\mathrm{RBP}$ & 26.4 (18) & 1.9 & 7.1 & 38 \\
\hline TBD & 27.2 (13) & 1.9 & 7.0 & 27 \\
\hline TGH & 38.1 (23) & 2.5 & 6.6 & 28 \\
\hline CGL & - & - & $=$ & $\overline{0}$ \\
\hline HW & $68.6(21)$ & 4.6 & 6.7 & 30 \\
\hline \multicolumn{5}{|c|}{ North } \\
\hline SLC & 21.8 (27) & 2.3 & 10.6 & 260 \\
\hline HBD & $36.6(24)$ & 2.2 & 6.0 & 269 \\
\hline RBP & 26.9 (20) & 1.9 & 7.1 & 295 \\
\hline TBD & 27.9 (16) & 1.8 & 6.4 & 289 \\
\hline TGH & 38.6 (25) & 2.4 & 6.2 & 213 \\
\hline CGL & 73.6 (17) & 4.1 & 5.6 & 21 \\
\hline HW & 69.4 (23) & 4.4 & 6.3 & 248 \\
\hline
\end{tabular}

Polish territories was respectively 95.9 and $95.0 \mathrm{~cm}$. The height in the withers of wild pigs living in the territory of Northern Poland was $95.7 \mathrm{~cm}$ and in Southern Poland $94.5 \mathrm{~cm}$.

The geographical differences which emerge from these comparisons, while they are not considerable, suggest that both domesticated and 
wild pigs were larger in Eastern and Northern Poland than in Western and Southern areas of the country.

In order to ascertain whether the above insignificance of differences results from an over-small area of observation, other areas were also included in the analysis - mainly other parts of Europe. Since an appropriately large amount of material exists, this was carried out for all the chronological periods. Major series of measurements of the bones

Table 6

Comparison of size of domestic pigs from Polish territory with those from other areas (on points scale).

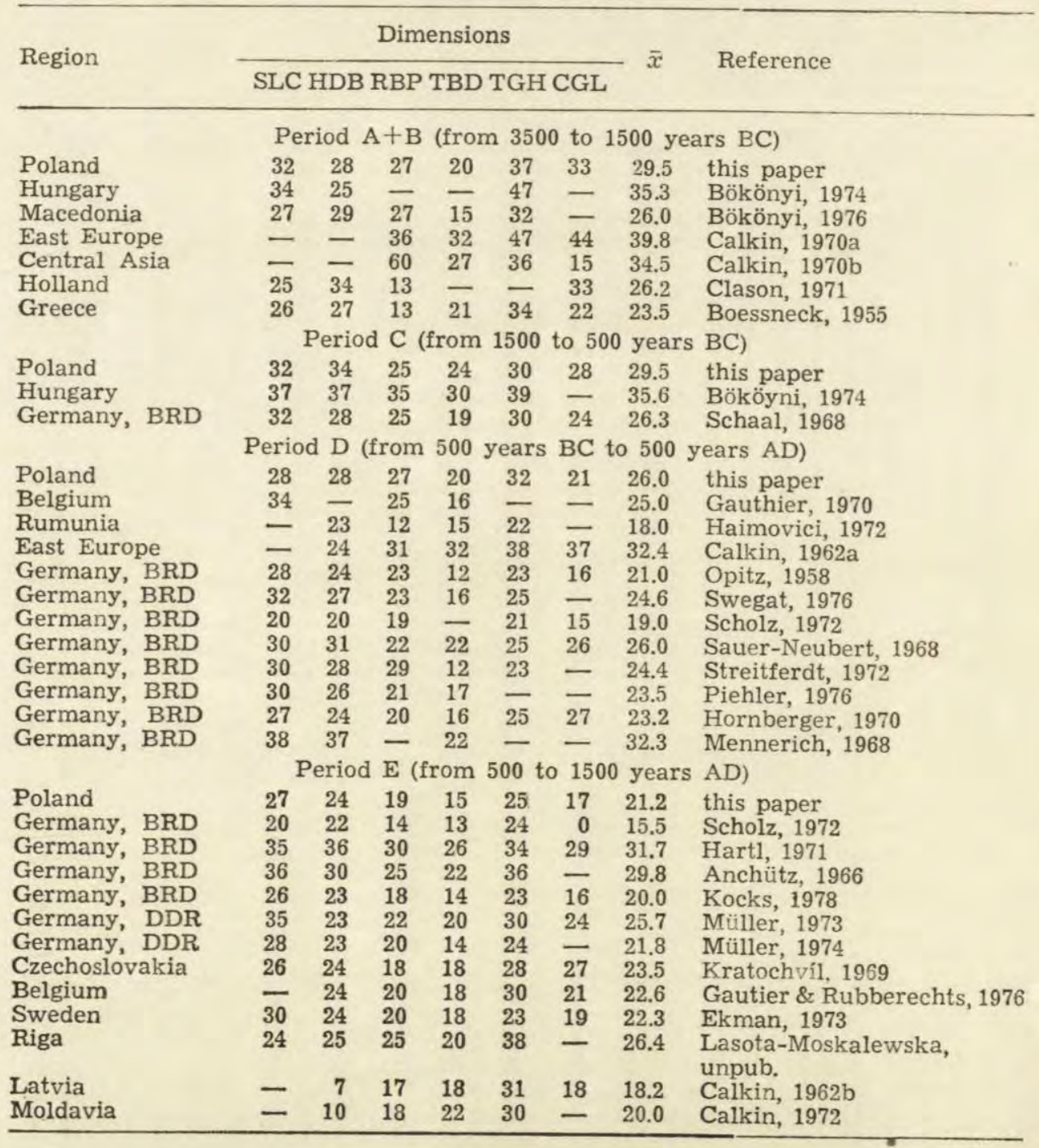


of domesticated pigs were selected from the literature, transposed onto the point scale, and the arithmetic mean was calculated (Table 6). Next, these were compared with the average number of points of all bones which determined the size of the skeleton of a domesticated pig in, Polish territory in particular chronological periods.

In the Neolithic (periods A and B), pigs from Holland and from the Southern parts of Yugoslavia and Greece were somewhat smaller than the average domestic pig from Polish territory. But pigs from the territories of Hungary, Eastern Europe and Central Asia were larger. In the bronze age (period C), pigs marginally smaller than those in Poland occurred in the territories of the German Federal Republic and Hungary. In the early iron age (period D), pigs from the territory of Belgium and the majority of pigs currently kept in the territory of the Federal Republic of Germany were almost identical with those kept in Poland. In Roumania, substantially smaller pigs occurred. The presence of decidedly larger pigs was noted in Eastern European territories. In the early mediaeval and mediaeval period (period E), pigs from the territory of Sweden, the German Democratic Republic, Belgium, Czechoslovakia and Moldavia were highly similar in size to those from Polish territory. Pigs from the territory of the German Democratic Republic exhibited in this period a high degree of size differentiation, as did pigs from Latvia.

\section{DISCUSSION}

Archaeozoological studies usually contain fewer specific data on the bones of domesticated pigs than on those of other domesticated animals, for example ruminants. This results from a variety of causes. Pig bones lying in the ground are subject to a greater degree of crumbling than for example the bones of ruminants or horses. Moreover, the basic aim of pig keeping was the production of meat, and therefore more often than in the case of other animals, pigs were killed at a relatively early age. This is indicated by almost all analyses of the percentage of bones of young animals found in food remains (Kratochvíl, 1981; Kobryń \& Serwatka, 1984; Molenda, 1984, 1985; Sobociński \& Kierkowska, 1985). Pig carcasses were butchered for consumption in such a way that only certain long bones were preserved in their entirety. Therefore it is rare to find whole bones in archaeozoological materials, making it exceptionally difficult to trace the process of change over time to which the skeleton of the pig was subject. A further difficulty in examining the material, which has been pointed out by many authors, is the imprecise designation of remains of domestic pigs and wild pigs, due to their 
similarity. Nonetheless, the accumulation of a considerable number of archaeozoological studies dealing with Polish territory has made it possible to collect measurement material which is sufficiently representative to provide a basis for evaluation of the changes in the size of some morphological characteristics over a period of about 5000 years.

The size of the skeleton of the domestic and wild pig from the Neolithic to the early iron age does not exhibit the regularity of evolutionary change. Higham (1986) came to a similar conclusion in his examination of the remains of domesticated animals from archaeological sites in Switzerland and Denmark which corresponded to our own in chronology. Some dimensions diminished over this time and others increased, while still others remained unchanged. Of course, in our own research this may be linked with the random grouping of materials dated in particular millennia, and the rather small number available for the earlier periods. It may also result from the fact that this evaluation is based mainly on breadth characteristics, and in the case of length characteristics does not deal with the long bones, which as we know from evolutionary research into the skeletons of other species were those which changed most greatly over time (Lasota-Moskalewska, 1980; Driesch, 1983; Kobryń, 1984). This result may suggest however that the dimensions of the skeleton of the domesticated and wild pig over the period from the Neolithic to the early iron age were fairly stable and subject to local variations, without showing a tendency to changes in any one direction. This suggestion is on the whole feasible, if we take into account the fact that pig rearing in this period must have been very primitive. Pigs which were grazed in deciduous forest had opportunities for unrestrained contacts with wild pigs, which exhibit a greater facility for living close to human settlements than other nondomesticated animals. This characteristic of wild pigs may have led to a considerably greater frequency of cross-breeding between wild and domesticated individuals than was the case for example with domesticated cattle, and also to the taming of young wild pigs and their introduction to herds of domesticated pigs. Attention has already earlier been drawn to these possibilities (Cabon, 1958; Jarman, 1971). The absence of isolation of the domestic from the wild form, and the almost identical conditions of existence of the two forms, did not provide the basis for the appearance of new characteristics linked with domestication (Higgs \& Jarman, 1969).

The domestic pig is an animal used mainly for the supply of meat and fat. This is the case at present and there is no reason for thinking that things were different in the pre-historic period. If therefore selective 
breeding took place, the criteria on which it was based must have been uncomplicated and leading in one direction.

A clear diminution in the dimensions of the skeleton of the domestic pig can be observed only in the period from the early iron age to the Middle Ages. In this same period, some dimensions of the skeleton of the wild pig also diminished. This convergence permits us to suggest that it may have been partly influenced by ecological factors, like for instance a reduction in the area of deciduous forest, which was the natural habitat and source of food of both the domestic and wild pig. The diminution in the skeleton size of the domestic pig was however greater than in the case of the wild pig. This difference may have resulted from the action of conditions linked with domestication. It is possible to discern here the effect of increasing isolation of the domesticated pig from its natural ecological habitat. The growth of towns and the need to supply their inhabitants with meat in large quantities made it essential to keep pigs near to the homestead, to limit their freedom of feeding and to change their diet to other kinds of food, for example, kitchen waste. This could have removed vitamin-rich vegetable elements from their diet. Domesticated pigs could therefore have remained a phenotypically short-statured form of their species. Pigkeeping near to the homestead may also have entailed a reduction in opportunities to cross domesticated pigs with wild pigs.

However, differences between domestic and wild pigs in the Middle Ages affected not only the dimensions of the skeleton and height in the withers. They can also be found in the microscopic structure of bone tissue (Lasota-Moskalewska \& Moskalewski, 1980). Unfortunately we do not know whether these differences occurred so early. But we may accept that there is a high degree of probability that they have continued to the present day and are perhaps even intensifying. Knief (1978) attested differences in the structure and the chemical composition of bone tissue, and the concomitant physical properties, between domestic and wild pigs in the contemporary period.

It is probable that the differences between the domestic and wild pig already in the early mediaeval and mediaeval period were not only phenotypical in character but were also the effect of genetic changes. It is possible that selective breeding, preferring individuals with smaller skeleton dimensions in relation to the meat mass, and also animals which would supply more tasty meat (e.g. grown around with fat), intensified. We may conclude that in the Middle Ages, pig breeders began to develop a race of pigs which would be able effectively to fulfil the basic purpose of their keeping. The great significance of pigs in human consumption in the Middle Ages is attested by the generally well-known fact that 
pig remains are the most numerous in the osteological material from this period, and that they usually occupied first place in the list of domesticated animals.

The greatest divergence between domestic and wild pigs in the process of diminution of size can be observed in the withers height. From the Neolithic to the Middle Ages, the height in the withers of the wild pig diminished by $2.2 \%$ from the initial size, and that of the domestic pig by $8.0 \%$. The occurrence of this final difference was preceded by the process of development of dimorphism between the two forms of animals.

It has been shown that the increasing difference in height in the withers of these two forms of animals was fast in the earliest periods that is, from the Neolithic to the bronze age - and in the latest periods - that is, from the early iron age to the Middle Ages. In the second stage, the process is fairly clear and the reasons have been explained above. But in the earlier periods this phenomenon is more difficult to explain because of the undoubted primitiveness of pigkeeping at this time, and also the fact that it is very doubtful whether selective breeding was practiced. Perhaps even this early stage of closer cohabitation between the domesticated pig and man brought certain changes in the pig's conditions of life. This would concern mainly a restriction of its grazing area and the composition of its feed. This could have been reflected in the form of phenotypical changes in the size of the skeleton, leading to shortness of stature. It should be emphasized that height in the withers was calculated mainly on the basis of the longest length of the long bone, and that these characteristics, as we know, are the most labile and react more swiftly to changes in life style than the breadth characteristics that formed the basis of the present study. Teichert (1970) obtained a different picture of the changes to which height in the withers in domestic and wild pigs was subject from that described above. The height of both domestic and wild pigs only diminished in the La Tene period, and in the Middle Ages reached similar proportions to those obtaining in the Neolithic. It would appear that this effect is a result of the heterogeneity of the material examined. Almost certainly, the magnitude of the arithmetic means obtained was affected by over-large regional differentiation. Apart from this, the author in question does not distinguish the transitional form between the wild and domestic pig, which may also influence considerably the average value obtained for the two remaining forms of the animals.

In the early mediaeval and mediaeval period, when both forms of the species Sus scrofa attained the greatest dimorphism in height in 
the withers, individual dimensions of the skeleton vary to a differing extent.

The differences between the domestic and wild pig are also revealed in the ratio of breadth of the trochlea to breadth of the distal end of the humerus. From the Neolithic to the Middle Ages, the breadth of the trochlea in relation to the breadth of the distal end of the humerus is smaller in the wild pig. This is understandable, since greater development of the epicondyle of the humerus may be expected in the wild pig, this being the site of the insertion of the muscles responsible for locomotion. One might suggest that the low value of this index provides evidence that the animal enjoyed greater proficiency in movement. In the Neolithic and the bronze age, the magnitude of this index does not differ significantly between the domestic and wild pig, although it does clearly begin to differ at the beginning of the iron age and remains different in the Middle Ages. At the same time, over the whole period of about 5000 years, the value of this index substantially increased in domestic pigs. One might conclude that the intensity of locomotion was seriously reduced in domestic pigs, and that this was expressed in poorer development of the epicondyle of humerus. This is yet further evidence that the evolution of the skeleton of the domesticated pig led to diverse modifications in it, and did not merely consist in harmonious diminution.

It is common to observe differentiation in the size of animals of the same species in relation to geographical region. In the case of wild animals, this differentiation is caused by varied ecological conditions in different regions, but in the case of domesticated animals there are usually two factors to be considered. On the one hand, the same ecological factors operate, but less acutely because of the greater isolation of these animals from their natural living conditions. On the other hand, the level of husbandry is of fundamental significance, together with the degree of dependence of the animals on their keepers, the intensity and aims of the application of selective breeding, and also the fact that the groups of animals being compared could have been descended from ancestors domesticated in another place of period of time.

Among pigs bred in the Middle Ages in Polish territory, no geographical differentiation is apparent. The interpretation of this result could varv: 1) in Polish territory in the Middle Ages, there were no natural geographical or civilization barriers which would provide obstacles to the complete translocation of populations of pigs; 2) all domestic pigs originated from one homogenous population of wild pigs; 3) the area of Poland is too small a territory for possible regional differences to emerge. 
In the Neolithic an increase in the size of the skeleton of the domesticated pig in two directions can be observed: from South to North and from West to East. The zone containing the largest pigs would include Hungary and Poland. Because of the number of sites which we might take into consideration, it would be difficult to say whether domesticated pigs from Northern Europe were larger or smaller, or whether in fact there was an optimal region of Central Europe. Apart from this, it would seem that the optimal zone for pig size is also Eastern Europe.

In the bronze age and early iron age there are too few comparative data, but those which are available do not contradict the account of the tendency which occurred in the Neolithic.

In the early mediaeval and mediaeval period, we have no extreme data for Southern and Eastern Europe. It is therefore difficult to say whether the tendencies observed in earlier epochs were maintained. It should be stressed that geographical differentiations in the size of wild pigs can also be observed in the contemporary period. Wild pigs occurring in the territories of Western and Central Europe are smaller than wild pigs from South East Europe (Pucek, 1984). Brink and Haltenorth (after Teichert, 1970) also claimed that the size of wild pigs increased from West to East. These tendencies were in accordance with the differences that we observed in the size of domestic pigs.

In the early mediaeval and mediaeval period, a fairly considerable differentiation in the size of domestic pigs has been observed in the territories of the Federal Republic of Germany and Latvia. This probably results from the varied level of advancement in husbandry in different human settlements in these territories. It has for example been found that in the 13th century the size of pigs kept at Riga was substantially greater than that of pigs from other places in mediaeval Latvia. This fact may be linked with the growth of German settlement in Riga in this period, and the possible import of animals. The pigs in Riga therefore may not have been representatives of a local population. On the basis of these results, it is necessary to emphasise the importance of examining individual sites on the basis of their differences, both ecological and historical.

The differentiation of the material in respect of sex proved impossible in our study for either the domestic or the wild pig. Sexual dimorphism appears in both forms, as we know, mainly in the varied size of the tusks, and frequently greater height in the withers in the case of boars. The differences in absolute dimensions are to such an extent discrete that they do not appear in a way that would permit identification of sex.

The point scale that we have developed contains ranges of variability 
for bone dimensions and height in the withers jointly for domestic and wild pigs. There is a justification for placing the whole range of variability of both these forms on one common scale. The numerical distributions that we have worked out show that almost all the dimensions of domesticated and wild pigs examined overlap constantly, indicating the existance of transitional zones. The range of these zones varies, depending on the characteristic in question and the chronological provenance of the material. If we take the simplest pattern, we can say that the transitional zone falls between 40 and 60 points. We suppose that this zone contains dimensions of large domestic pigs, small wild pigs, and transitional forms between the wild and domestic pig. Considerably more materials originating in the earlier periods, that is in the Neolithic, the bronze age and the beginning of the iron age, fall within the transitional zone. In the Middle Ages the transitional zones are smaller, or do not occur at all.

Interpretation of the attribution of bones falling within the transitional zones (Fig. 5, areas not hatched) requires additional information to be taken into consideration. If it is a bone of a very compact structure and with clear sculpting, one may conclude that it came from a wild pig of somewhat smaller dimensions (e.g. a sow, or a fairly young individual). In the Middle Ages, a bone whose dimensions fall within the transitional zones will more frequently come from a wild than from a domestic pig, since mediaeval wild pigs were a little smaller than those in the earlier periods. However, in the Neolithic material, one may expect that a bone of this kind came from a transitional form between the wild and domesticated pig - which is often distinguished in archaeozoological studies as "a wild form of the domesticated pig".

A transitional form is sometimes interpreted as a cross between a wild and domesticated pig. This interpretation cannot be fully justified in the light of empirical research, for it fails to take into account the phenomenon of heterosis, which also occurs as a result of cross-breeding of domestic and wild pigs (Żurowski et al., 1970).

On the basis of examination of the magnitude of the dimensions of bone breadth, it is not possible to establish whether domestic pigs from Polish territory originate from the European wild pig (Western) or from the Asian (Eastern) one. An answer to this question could be provided by analysis of the structure of the skull, and in particular the shape of the lacrimal bone. However, the majority of authors who have these elements of the skeleton at their disposal emphasize that the shape of the lacrimal bone in domestic pigs occurring in Polish territory indicates that they originate from the European wild pig (e.g. Gawlikowski \& Stępień, 1984; Molenda, 1984, 1985; Sobociński \& Kierkowska, 1985) 
One may assume a priori, on the basis of the continuing ease with which young wild pigs can be tamed, and the crossing of wild pigs with domestic pigs, that the domestication of pigs in Polish territories probably took place locally, and was extended in time. This has been indirectly attested by the finding that there were more transitional forms between the wild and domestic pig in the earlier periods than in the later. The dimorphism of the size of the elements of the skeleton examined in the two forms also grew with the passage of time.

Changes in the size of the skeleton of pigs living in domesticated conditions took place continuously, but at an uneven pace for various dimensions. Thanks to this, the skeleton of the contemporary domestic pig is not only smaller than that of the wild pig, but also has somewhat different proportions. It would seem that in addition to conscious selection applied by pig-breeders, the main factor conditioning these changes was the restriction of the locomotion of the domesticated pig.

Acknowledgements: The authors would like to thank Professor Marian Sobociński for making available to them certain unpublished pig bone dimensions.

\section{REFERENCES}

1. Anschütz K., 1966: Die Tierknochenfunde aus der Mittelalterlichen Siedlung Ulm-Weinhof. Diss., 1-54. München.

2. Boessneck J., 1955: $\mathrm{Zu}$ den Tierknochen aus neolithischen Siedlungen Thessaliens. Bericht d. Röm.-Germ. Kom., 36: 1-51.

3. Bogolubski S., 1968: Pochodzenie i ewolucja zwierząt domowych. PWRiL: $1-462$. Warszawa.

4. Bökönyi S., 1974: History of domestic mammals in Central and Eastern Europe. Akadémiai Kiadó: 1-597. Budapest.

5. Bökönyi S., 1976: The vertebrate fauna from Anza. [In: "Neolithic Macedonia as reflected by excavation at Anza, Southeast Yugoslavia". M. Gimbutas ed.]313-374. Los Angeles, California.

6. Bökönyi S., 1983: Domestication, dispersal and use of animals in Europe. World Animal Science, 1: 1-20.

7. Caboń K., 1958: Untersuchungen über die Schädelvariabilität des Wildschweines, Sus scrofa L. aus Nordostpolen. Acta theriol. 2: 107-140.

8. Calkin V. I., 1962a: Životnovodstvo i ochota v rannem železnom veke. Mater. Issled. po Archeol. SSSR, 107: 5-96.

9. Calkin V. I., 1962b: Fauna iz raskopok archeologičeskich pamjatnikov sredniovekovoj Pribaltiki. Mater. Issled. po Archeol. SSSR, 107, 97-140.

10. Calkin V. I., 1970a: Drevnejšie domašnie životnye Vostočnoj Evropy. Izdat. Nauka: 1-279. Moskva.

11. Calkin V. I., 1970b: Drevnejšie domašnie životnye Srednej Azii. BuI. Mosk. Obšč. Isp. Prirody. Otd. Biol., 75: 145-159.

12. Calkin V. I., 1972: Fauna iz raskopok slavianskich pamiatnikov Moldavii. Trudy Mosk. Obšč. Isp. Prirody, 48: 38-66.

13. Clason A. T., 1971: The flint-mine workers of Spiennes and Rijckholt - St. Geertruid and Their Animals. Helinium, 11: 3-33. 
14. Corbet G. B., 1978: The Mammals of the Palaearctic Region: a taxonomic review. British Museum (Natural History). Cornell Univ. Press: 1-314. London and Ithaca.

15. Cram C. L., 1979: Neolithic pig keeping in Highland New Gwinea and prehistoric Europe. Proc. of the Third Intern. Archaeozool. Conf., Agricult. Acad., Szczecin, 1: 329-339.

16. Driesch von den A., 1976: A guide to the measurement of animal bones from archaeological sites. Peabody Mus. Bull., 1: 1-136.

17. Driesch von den A., 1983: Zur Haustierhaltung in den vor- und frühgeschichtlichen Kulturen Europas. Koll. z. Allgem. u. Vergl. Archäol., 4: 25-58.

18. Duerst J. U., 1926: Vergleichende Untersuchungsmethoden am Skelett bei Säugern. Urban und Schwarzenberg: 125-530. Berlin, Wien.

19. Ekman J., 1973: Early Mediaeval Lund - the fauna and the landscape. An osteological investigation of bone remains from the early mediaeval settlement. Archaeol. Lund., 5: 1-110.

20. Gauthier A., 1970: Les restes d'animaux du vicus romain de St-Mard. Pays: gaumais, 32: 183-194.

21. Gauthier A. \& Rubberechts V., 1976: Animal the Senecaberg Fortification (Grimbergen, Belgium, 12th century). Bul. d. Mus. Royaux d'Art et d. Hist. 48: $49-84$.

22. Gawlikowski J. \& Stępień J., 1984: Zwierzęce szczątki kostne ze stanowiska 1 w Stargardzie Szczecińskim, Rocz. AR w Poznaniu 154, Archeozool., 5: 19-34.

23. Haimovici S., 1972: Date privind resturile de animale descoperite in Asezarea Getica da la Zimnicea. Anal. Stint. a. Univ. "Al. I. Cuza" Din Iasi, a. Biol., 18: 191-204.

24. Hartl M., 1971: Die Tierknochenfunde aus der Wüstung Wülfingen. Diss., 1-53. München.

25. Higgs E. S. \& Jarman M. R., 1969: The origins of agriculture. Antiq., 43: $31-41$.

26. Higham C., 1968: Size trends in prehistoric European domestic fauna, and the problem of local domestication. Acta zool. fenn, 120: 2-21.

27. Hornberger M., 1970: Gesamtbeurteilung der Tierknochenfunde aus der Stadt auf dem Magdalensberg in Kärtnen (1948-1966). Kärn. Museumschr., 49: $1-144$.

28. Jarman M., 1971: Culture and economy in the north Italian Neolithic. World Archaeol., 2: 255-265.

29. Knief W., 1978: Untersuchungen zum Feinbau einiger Röhrenknochen von Wildund Hausschweinen (Sus scrofa L.). Zool. Jb. Anat. Bd., 99: 381-420.

30. Kobryń H., 1984: Zmiany niektórych cech morfologicznych konia w świetle badań kostnych materiałów wykopaliskowych z obszaru Polski. Rozpr. nauk. i Monogr. Wyd. SGGW-AR: 1-78. Warszawa.

31. Kobryń H. \& Serwatka S., 1984: Szczątki kostne świni domowej (Sus scrofa f. domestica L., 1758) w materiale wykopaliskowym $\mathrm{z}$ średniowiecznego grodu w Kaliszu-Zawodziu. Archeol. Pol., 29: 415-425.

32. Kocks B. M., 1978: Die Tierknochenfunde aus den Burgen auf dem Weinberg in Hitzacker/Elbe und in Dannenberg (Mittelalter). Diss., 1-227. München.

33. Kratochvíl Z., 1969: Die Tiere des Burgwalles Pohansko. Acta Sci. Nat. Brno, 3: $1-39$.

34. Kratochvíl Z., 1981: Tierknochenfunde aus der grossmährischen Siedlung Mikulčice. I. Das Hausschwein. Stud. Archeol. Ust. CAV, 9: 3-143. 
35. Lasota-Moskalewska A., 1980: Morphotic changes of domestic cattle skeleton from the neolithic age to the beginning of the iron age. Wiad. archeol., 45: $119-163$.

36. Lasota-Moskalewska A., 1984: The skeleton of a prehistoric cow with characteristics of both Primigenious and Brachycerous cattle. Ossa, 9: 53-72.

37. Lasota-Moskalewska A. \& Moskalewski S., 1980: Microscopic comparison of bones from mediaeval domestic and wild pigs. Ossa, 7: 173-178.

38. Mennerich G., 1968. Römerzeitliche Tierknochen aus drei Fundorten des Niederrheingebiets. Diss., 1-175. München.

39. Molenda O., 1984: Szczątki kostne świni (Sus scrofa f. domestica) z wczesnośredniowiecznego Ostrówka w Opolu. Rocz. AR w Poznaniu 154, Archeozool., 9: $67-86$.

40. Molenda O., 1985: Szczątk kostne świni (Sus scrofa f. domestica) z wczesnośredniowiecznych stanowisk archeologicznych we Wroclawiu. Rocz. AR w Poznaniu 164, Archeozool., 10: 25-42.

41. Müller H. H., 1973: Das Tierknochenmaterial aus den frühgeschichtlichen Siedlungen von Tornow, $\mathrm{Kr}$. Calau. [In: "Die germanischen und slawischen Siedlungen and des mittelalterliche Dorf von Tornow, Kr. Calau". J. Herrmann, ed.]. 267-310. Berlin.

42. Müller H. H., 1974: Die Tierreste aus der slawischen Burganlage von Arkona auf der Insel Rügen. ZfA Z. Archäol., 8: 255-295.

43. Opitz G., 1958: Die Schweine des Latene-Oppidums Manching. Stud, vor- u. frühgesch., Tierrest. Bayerns, 3: 1-40.

44. Piehler W., 1976: Die Knochenfunde aus dem spätrömischen Kastell Vemania. Diss., 1-140. München.

45. Pucek Z, 1984: Klucz do oznaczania ssaków Polski. PWN: 1-382. Warszawa.

46. Sauer-Neubert A., 1968: Tierknochenfunde aus der römischen Zivilsiedlung in Hüfingen̉. 'Diss., 1-131. München.

47. Schaal F, 1968: Tierknochenfunde aus der Siedlung "Am Hetelberg" bei Gielde/ Niedersachsen. Diss., 1-98. München.

48. Scholz E., 1972: Die Tierknochenfunde von den Burg Schiedberg bei Sagogn in Graubünden, Diss., 1-169. München.

49. Sobociński M. \& Kierkowska M., 1985: Szczątki kostne świni (Sus scrofa f. domestica) i dzika (Sus scrofa L., 1758) z wczesnośredniowiecznych stanowisk archeologicznych na Kujawach. Rocz. AR w Poznaniu 164, Archeozool., 10: $129-151$.

50. Streitferdt U. K., 1972: Osteoarchäologische Untersuchungen an Tierknochenfunden aus vier Römischen Stationen im Süddeutschen Raum. Diss., 1-118. München.

51. Swegat W., 1976: Die Knochenfunde aus dem römischen Kastell KünzingQuintana. Diss., 1-135. München.

52. Teichert M., 1969: Untersuchungen zur Berechnung der Widerristhöhe bei vorund frühgeschichtlichen Schweinen. Kühn-Archiv., 83: 237-292.

53. Teichert M., 1970: Grössensveränderungen der Schweine von Neolithikum bis zum Mittelalter. Arch. Tierz., 13: 229-240.

54. Zeuner F. E., 1963: Domesticated animals. Hutchinson: 1-560. London.

55. Żurowski W., Siudowa H. \& Gałka B., 1970: Effect of single pig's blood addition on the local wild boar (Sus scrofa) population. Transactions of the IX Intern. Cong. of Game Biol., 235-238. Moscow.

Received, December 20, 1985. Accepted, July 31, 1986. 
Alicja LASOTA-MOSKALEWSKA, Henryk KOBRYN i Krzysztof SWIEŻYÑSKI

\section{ZMIANY WIELKOSCI SWINI DOMOWEJ I DZIKA OD NEOLITU DO SREDNIOWIECZA NA TERENIE POLSKI}

\section{Streszczenie}

Zbadano zmiany w czasie sześciu wymiarów kości i wysokości w kłębie świni domowej i dzika. Badania przeprowadzono w oparciu o materiały archeozoologiczne ze 120 stanowisk na terenie Polski (Tabela 1).

W ciągu około 5 tys. lat wymiary szkieletu świni domowej zmniejszyly się bardziej niż wymiary szkieletu dzika (Ryc. 2). Badane cechy morfologiczne zmniejszyły się w różnym stopniu, co doprowadziło do zmian w proporcjach szkieletu a jednocześnie świadczy o różnej reaktywności poszczególnych elementów kośćca na działanie tego samego zespołu czynników (Tabela 3).

Nie odnotowano wyraźnej zmienności geograficznej badanych cech u świni domowej i dzika $\mathrm{z}$ terenu Polski (Tabela 5). Zaobserwowano natomiast zróżnicowanie geograficzne wysokości świni domowej pochodzącej $\mathrm{z}$ terenu Polski i innych obszarów. W okresie od neolitu do średniowiecza odnotowano tendencję do występowania mniejszych świń domowych w Europie Zachodniej niż we Wschodniej. Swinie w Europie Srodkowej byly większe niż w Europie Południowej i Pólnocnej (Tabela 6).

W celach praktycznych skonstruowano skalę punktową obejmującą badane cechy (Ryc. 5). Zaznaczone na niej zakresy zmienności wymiarów charakterystyczne dla świni domowej, dla dzika i dla formy przejściowej ułatwią identyfikację niektórych kości. Skala ta pozwala również porównywać między sobą cechy różnie mianowane i o różnej randze wielkości. 